\title{
Pattern of transcription of the homeo gene Hox-3.1 in the mouse embryo
}

\author{
Hervé Le Mouellic, Hubert Condamine, and Philippe Brûlet \\ Unité de Génétique Cellulaire du Collége de France et de l'Institut Pasteur, 75724 Paris Cedex 15, France
}

\begin{abstract}
A cDNA from the Hox-3.1 locus, isolated from a 10.5-day postcoitum (p.c.) mouse embryo cDNA library, and the putative encoded protein are described. The spatial distribution of Hox-3.1 gene transcripts from late gastrulation to embryonic day 14.5 p.c. was monitored by in situ hybridization, using a cDNA probe. When first detectable in 8.5-day p.c. embryos, the transcripts are distributed in all the tissues of the posterior end. At later stages, the distribution becomes progressively spatially restricted and tissue specific. By 12.5 days p.c., transcription is localized most intensely in the neural tube region lying above the heart. The early transcription pattern thus appears to be compatible with a regionalizing role for the Hox-3.1 gene.
\end{abstract}

[Key Words: In situ hybridization; murine embryogenesis]

Received August 4, 1987; revised version accepted November 5, 1987.

Years of classical genetics and mutagenesis studies have led to the characterization of numerous genes involved in the development of Drosophila melanogaster (Martinez-Arias and Ingham 1986; Gehring 1987; Gergen 1987), many of which have recently become amenable to molecular analysis. A 183-bp protein-coding sequence, known as the homeo box, has been found in several homeotic and segmentation genes (Laughon and Scott 1984; McGinnis et al. 1984) and also in a maternally expressed gene (Mlodzik et al. 1985; MacDonald and Struhl 1986). The 61-amino-acid homeo domain, which shows homologies with regulatory and DNA-binding proteins (Laughon and Scott 1984; Shepherd et al. 1984), has been found with a high degree of conservation in many widely separate phylogenetic groups (McGinnis et al. 1984; Holland and Hogan 1986). This has led to speculation that the conservation of structure reflects analogous functions for these genes in embryogenesis of different species. If this is true, it would provide an opportunity to identify molecules involved in the development of those species in which access to developmentally meaningful genes is difficult.

Recent observations made on vertebrates support this hypothesis, as they have revealed further similarities with Drosophila. Homeo boxes have been found to be arranged in clusters in the genomes of man and mouse (Colberg-Poley et al. 1985b; Hart et al. 1985; Hauser et al. 1985; Duboule et al. 1986), a mouse homeo domain has been shown to bind DNA (Fainsod et al. 1986), and a Xenopus homeo protein is localized in the nucleus (Harvey et al. 1986). In addition, the transcription of homeo genes in man, mouse, and Xenopus embryos, as revealed by Northern blots, RNase protection assays, and in situ hybridization, appears to be spatially and temporally restricted in all cases studied so far (Gaunt et al. 1986; Carrasco and Malacinski 1987; Joyner and Martin 1987; Krumlauf et al. 1987; Utset et al. 1987; reviewed by Snow 1986; Schofield 1987).

This paper describes the cloning and sequencing of a cDNA from a previously identified mouse homeo gene, Hox-3.1 (Awgulewitsch et al. 1986; Breier et al. 1986). We also provide a description of Hox-3.1 transcription patterns between days 8.5 and 14.5 post coitum (p.c.) of mouse embryogenesis. We show that although Hox-3.1 transcripts eventually become specifically located in neural tissue, they are initially found in all tissues of the posterior region in 8.5- and 9.5-day p.c. embryos. We suggest that Hox-3.1 might be involved in embryo regionalization rather than in the determination of a particular cell lineage.

\section{Results}

Hox-3.1 genomic and cDNA cloning

Using a Drosophila homeo box probe from the Antennapedia (Antp) gene, we screened a mouse genomic DNA library under reduced hybridization stringency (see Materials and methods). We obtained 20 genomic DNA recombinant molecules. In one of them (Sou 6, Fig. 1), the homeo box was localized and identified as the Hox-3.1 homeo box by its nucleotide sequence and the restriction map of the genomic molecule (Awgulewitsch et al. 1986; Breier et al. 1986). An assay based on protection from RNase A digestion, using a mouse genomic 300base RNA probe containing the homeo box, showed that transcription of the Hox-3.1 locus is detectable in 10.5day p.c. whole embryos and visceral yolk sac but not in brain extracts of the same age (data not shown). A cDNA library was constructed in $\lambda$ gt 10 using poly(A)+ RNAs extracted from 10.5-day p.c. embryos. Screening with 


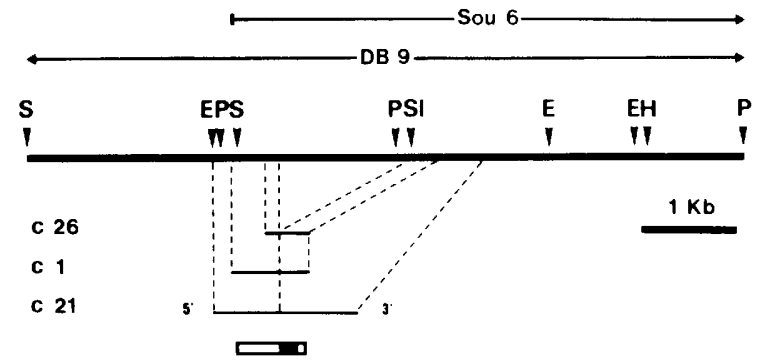

Figure 1. Partial restriction map of the mouse Hox-3.1 locus, including two genomic clones (Sou 6 and DB 9), the three sequenced cDNAs $(\mathrm{c} 26, \mathrm{cl}$, and $\mathrm{c} 21)$ and the open reading frame (ORF) with the homeo box in black. The dotted lines position the $5^{\prime}$ and $3^{\prime}$ ends of the cDNAs and the common intron on the genomic map (E) EcoRI; (H) HindIII; (P) PstI; (S) SstI; (Sl) SalI.

the same genomic probe yielded several cDNAs molecules. Three of them (Fig. 1) were analyzed and sequenced further.

\section{Structure of the CDNA and the encoded protein}

The nucleotide sequence of the largest cDNA /clone c21, $1470 \mathrm{bp}$ long) is shown in Figure 2 with some flanking genomic sequences, together with the conceptual protein encoded by the longest open reading frame (ORF), which includes the homeo box. The two smaller cDNA clones have a nucleotide sequence identical to that of c21. They were found to be primed at an internal poly(A) stretch (973-979). Comparison with genomic sequences showed the same 1.35-kb intron, located 2 codons upstream from the homeo box, in all three cDNAs. The poly(A) tail of $\mathrm{c} 21$ is added to a $\mathrm{G}$ residue instead of the more usual $\mathrm{C}$ or $\mathrm{T}$. There is no classical upstream polyadenylation signal (Birnstiel et al. 1985); the first such signal is found 54 bp downstream from the $3^{\prime}$ end of the c21 cDNA. Thus, it is conceivable that synthesis of c21 was initiated at an internal A-rich region able to pair with an oligo(dT) primer, rather than at the proper terminus of Hox 3.1 mRNA.

The largest ORF begins with an initiation codon perfectly matching the vertebrate consensus sequence CANCAUG (Cavener 1987). It is preceded by several stop codons in the three possible reading frames and codes for a putative protein of 242 amino acids $(27,710$ daltons). The Hox-3.1 protein contains the homeo domain close to its carboxyl terminus like other vertebrate homeo proteins characterized thus far, which also have similar sizes (see Fig. 3A and references in the legend). The deduced protein contains several regions homologous to other homeo proteins. The 61 -amino-acid homeo domain has already been reported (Awgulewitsch et al. 1986; Breier et al. 1986). It clearly belongs to the Antennapedia class $174 \%$ and $82 \%$ homology with Antp homeo box at the DNA and protein sequence levels, respectively). Two short sequences in the region aminoterminal to the homeo box display a substantial degree of conservation among several homeo proteins: The first 8 amino acids of the amino terminus are well conserved
(Fig. 3B), and another 6-amino-acid region just upstream from the homeo box, although coded by a different exon, is strongly conserved in the putative Hox-3.1 protein (Fig. 3C) when compared with the consensus sequence (Mavilio et al. 1986; Krumlauf et al. 1987). The aminoterminal end of the postulated protein does not show any further significant homology with other homeo proteins, except in its overall composition, which is mostly hydrophilic with high percentages of serine $(16 \%)$ and proline $(8 \%)$. The most noticeable feature of the carboxy-terminal sequence is a stretch that is very rich in glutamate residues ( 15 out of 21 amino acids). An acidic region of this type has already been reported for the Hox-1.1 locus, as judged from the genomic sequence downstream from the homeo box, where 15 glutamate codons were found just before a stop codon /ColbergPoley et al. 1985a).

\section{Transcription of the Hox-3.1 gene during mouse embryogenesis}

The cPS probe A 636-bp cDNA fragment, referred to as cPS, was selected as a probe for transcription studies. It extends $5^{\prime}$ from the SalI site to a PstI site and, therefore, does not contain the conserved homeo box sequence (Fig. 4C). Under stringent hybridization conditions (see Materials and methods), a single band was detected in Southern analysis of genomic DNAs (Fig. 4A). At lower reduced stringency, a partially homologous locus was detected using the cPS probe or using probes located 3' to the homeo box or inside the intron (data not shown). Northern blots of total RNAs extracted from embryos aged from 9.5 to 12.5 days p.c. reveal a broad band of transcript|s) with an apparent $3.2-\mathrm{kb}$ size (Fig. 4B). An apparent $5-\mathrm{kb}$ transcript is, in fact, due to probe trapping by the $28 \mathrm{~S}$ rRNA. An RNA species with the same mobility was also detected at the same stages using an antisense RNA probe generated from the same PstI-SalI cDNA fragment (data not shown), using a combination of stringent hybridization and washing conditions, and digestion of blots by RNases $A+T_{1}$, according to Melton et al. (1984). No signal was detected using the sense probe either by Northern analysis or by RNase protection assay (data not shown).

In situ hybridization To gain an insight into the spatiotemporal pattern of Hox-3.1 gene expression during mouse embryogenesis, we performed in situ hybridization experiments on cryostat sections of 7.5- to 14.5-day p.c. embryos. Both antisense and sense single-strand RNA cPS probes were used under stringent conditions of hybridization and washing (see Materials and methods). As no labeling was ever obtained using the sense cPS probe, which has the same polarity as the mRNA, the results described below all refer to the antisense probe.

Hybridization on parasagittal sections from 11.5- and 14.5-day p.c. embryos revealed an intense signal restricted to the posterior cervical region of the neural tube, directly above the heart in the 14.5-day embryo 


\begin{abstract}
ctctctctctctctctctetctctctctctctctctctctctctcetctcetctccetctctctct ctctctctctctctctct getcgetcgctcgctcgctcgctcgectgtcttcatgtcgtg gatt gat ga ac gc gaatc gcgtgtaag g gccgccaccgcc gggag tctgag ga at tc gcctgggcT GTTAGAGGAAAGAGCTAAGTGAGAGCGCGCG CTC TACC I ACC GACAGT GAG CAGAGAGCT G CAGCCGCCC GAGCCCG CAGCCGG CACCGCGCCCC CACCTGCC CAGCCCC CAG CCCAG CAG TCCAG CCCGGGGGAG CCGGCCAGCI TGGGGTICGG TCCCGGGGGGAGGGGAGTITCGGGGA IACCCGG 190

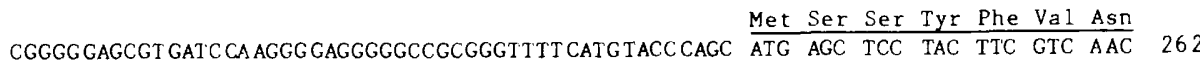
Pro Leu Phe Ser Lys Tyr Lys Gly Gly Glu Ser Leu Glu Pro Ala Tyr Tyr Asp Cys Ar 8 CCC CTG TTT TCC AAA TAC AAA GGC GGC GAG TCC CTG GAA CCG GCC TAT TAC GAC TGC CGG Phe Pro Gln Ser Val Gly Arg Ser His Ala Leu Val Tyr Gly Pro Gly Gly Ser Ala Pro TTC CCT CAG AGC GTG GGC AGA AGC CAI GCG CTG GIG TAC GGG CCC GGC GGC TCC GCG CCC Gly Phe Gln His Ala Ser His His Val Gln Asp Phe Phe His His Gly Thr Ser Gly Ile GGT ITC CAG CAC GCC TCG CAC CAC GTC CAA GAC TTC TTC CAC CAC GGC ACC TCC GGC ATC Ser Asn Ser Gly Tyr Gln Gln Asn Pro Cys Ser Leu Ser Cys His Gly Asp Ala Ser Lys TCC AAC ICG GGC IAC CAG CAG AAC CCA IGC ICG CTG AGC TGC CAC GGA GAC GCC TCC AAA 502 Phe Tyr Gly Tyr Glu Ala Leu Pro Arg Gln Ser Leu Tyr Gly Ala Gln Gln Glu Ala Ser TTC TAI GGC TAC GAG GCG CTC CCC AGA CAG ICC CTT TAT GGG GCT CAG CAA GAG GCG AGC Val Val Gln Tyr Fro Asp Cys Lys Ser Ser Ala Asn Thr Asn Ser Ser Glu Gly Gln Gly GTG GTG CAA TAT CCC GAC TGT AAA TCC ICC GCC AAC ACI AAC AGT AGC GAA GGA CAA GGC His Leu Asn Gln Asn Ser Ser Pro Ser leu Met Phe Pro Trp Met Arg Pro his Ala Pro CAC ITA AAT CAG AAC TCG TCT CCC AGC CTC ATG TTI CCA TGG ATG AGA CCC CAC GCT CCT 682 G1y Arg Arg Ser Gly Arg Gln Thr Tyr Ser Arg Tyr Gln Thr Leu Glu Leu Glu Lys Glu GGG CGG CGC AGC GGT CGA CAA ACT TAC AGC CGG TAT CAG ACC ITG GAA CTA GAG AAG GAG 742 Phe Leu Phe Asn Pro Tyr Leu Thr Arg lys Arg Arg Ile glu Val Ser His Ala Leu Gly TTT CIC TTT AAT CCI TAT TTG ACC AGA AAG CGC CGG ATT GAA GTC TCT CAC GCC CTG GGA 802 Leu Thr Glu Arg Gln Val Lys Ile Trp Phe Gln Asn Arg Arg Met Lys Trp Lys lys Glu CIG ACA GAA AGA CAA GTG AAG AIT IOG TTC CAG AAI CGA AOG ATG AAG TGG AAA AAG GAG 862 Asn Asn lys Asp Lys Le u Pro Gly Ala Arg Asp Glu Glu Lys Val Glu Glu Glu Gly Asn AAC AAC AAG GAT $A A A$ C1G CCT GGG GCC CGA GAT GAG GAG AAG GTG GAA GAA GAA GGG AAT 922 Glu Glu Glu Glu Lys Glu Glu Glu Glu Lys Glu Glu Asn Lys Asp *** GAG GAA GAG GAG AAA GAG GAG GAG GAA AAG GAA GAA AAI AAG GAC TAA GGAAAAAAAGAGAGA 985 GAAAATCAGCCCCCCCCCAGCAACTCCCTTGAAGTTTCGTTTIAIGGTAGCAGATAAAT TGAGAAGTTTACGACTGTCA 1064 TTTGCTT'I TATAGAGA ATAGA AT GACACT CACAACTC TA AC TACCTGI CAGA TAGTTGCAGCTCTGCTTIT TAT TACCTT 1143 TGGGCTTCCCCCACTCITIATTTGTCTGGGGTTGGGAGGGGGACCTGAGACACAGGGAAAAGTTCTGTTCTACTCCA 1222 TGCCCAGCATACACTCTCJTGTTCCTGCICC CACCTTCT GAGCCCTTCCCCATAAAGTC TAACCCIII CACACACACACA 1301 CACACACACACACACACACACACACACTTCTCI CCACACTCCCICT TCACGGTGCTTCTCTGGTATT TATTTTAAAAGG 1380

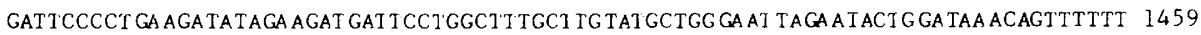

TTIAATGAAAAga agaaggaaaaaacaggaagggggaatgaaggaaaat taaaagaaataa 1470
\end{abstract}

Figure 2. The nucleotide sequence of the $\mathrm{c} 21 \mathrm{cDNA}$ clone, flanking genomic regions, and the predicted amino acid sequence of the protein. The cDNA sequence is in uppercase letters, and the flanking genomic sequences is in lowercase letters. Numbering starts at the first $5^{\prime}$ nucleotide of the cDNA. ( $\triangle$ ) The position of the intron, whose splicing sites (ACG $\uparrow$ GTGAGA TTCTGTTCAG $\uparrow$ CT) fit well with the known consensus sequence (Cech 1983). The sequence of the putative Hox-3.1 protein is shown above the ORF. Two conserved peptide regions are underlined (see text and Fig. 3B,C). The homeo domain is printed in boldface type. Note the two long (CT) repeats in the $5^{\prime}$-genomic sequence, a potential stable secondary structure between nucleotides 59 and $241 /-141 \mathrm{kcal} / \mathrm{mole}$ ), and a $(\mathrm{CA})_{19}$ repeat in the $3^{\prime}$ UT cDNA sequence $(1290-1328)$.

and somewhat more posterior in the 11.5-day embryo (Fig. 5).

Hybridizations on transverse sections of 12.5-day p.c. embryos confirmed this distribution. Intense labeling was detected in the neural tube of sections from the cardiac region (Fig. 6b,c), fading out gradually in more posterior regions (Fig. 6d). No RNA was detected in the anterior part of the embryo (Fig. 6a). The labeling was concentrated in the so-called mantle region of the neural tube and virtually absent from the marginal layer. Absence of labeling was noticeable in head tissues, neural or otherwise, heart, lung, liver, and limb buds.

Similar transverse sections made of 10.5-day embryos cross the neural tube twice owing to the curvature of the embryo (Fig. 7III). Figure 7, I and II, shows two transverse sections, each with two neural tube regions. In both of them, the labeling is present only on the more anterior section of the neural tube, where it is not distributed 
A

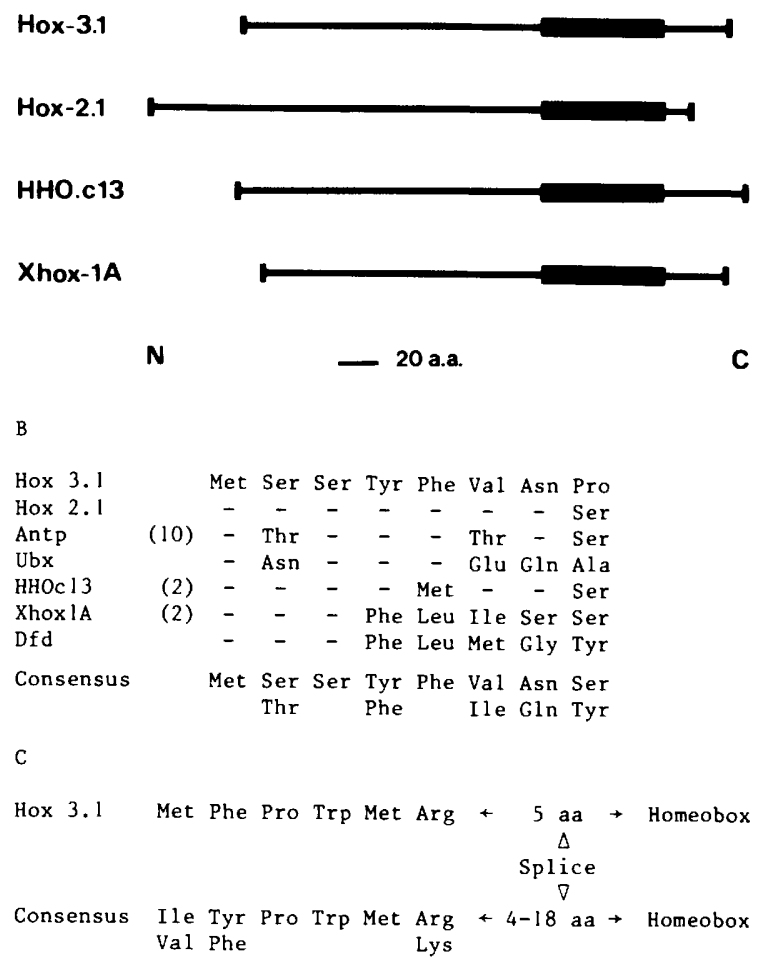

Figure 3. Conserved features of the homeo proteins. (A) Schematic scale representation of the vertebrate homeo protein sequences deduced from the published cDNAs; the wider bar represents the homeo box. $(\mathrm{N}, \mathrm{C})$ The amino and carboxyl termini. (B) Amino-terminal sequence of homeo proteins and the deduced consensus sequence. Amino acid identity with Hox-3.1 is indicated by a dash. When the ORF begins upstream, the number of additional amino acids is indicated in parenthesis. (C) The second conserved region in Hox-3.1 and the consensus sequence. The distance between this region and the homeo box, coded by a different exon, is indicated in amino acids. Sequence references: Mouse Hox-2.1 (Krumlauf et al. 1987); human HHOc13 (Mavilio et al. 1986); Xenopus Xhox 1A (Harvey et al. 1986); Drosophila Antp, Ubx, Dfd (Schneuwly et al. 1986; Regulski et al. 1987; Wilde and Akam 1987).

uniformly. The signal in the ventral horns is always much stronger than that in more dorsal regions of the neural tube (Fig. 7b3). However, some labeling could also be detected occasionally, although at a much lower level, in distal regions of the neural tube located posteriorly to the hindlimb bud (data not shown). Again, the signal there was essentially confined to the ventral horns. The neural tube is not the only organ that hy. bridizes with the probe in the 10.5-day p.c. embryo. The labeling of the dorsal region of somites in the thoracic region of the embryo is particularly striking (Fig. $7 \mathrm{a} 2, \mathrm{a} 3$ ). It should be noted that the anterior limit of labeling in somites is posterior to that in the neural tube. (The yolk sac is also positive, in agreement with RNA protection assays.) No significant labeling could be detected elsewhere in the 10.5-day p.c. embryo.

The presence of Hox-3.1 transcripts in a variety of nonneural tissues is even more obvious in sections of 9.5-day p.c. embryos (Fig. 8a,b,c). In fact, all tissues were labeled in sections from the posterior trunk region (located posteriorly to the forelimb bud) and the caudal region, including the region of the embryo where the dorsal aorta splits into two distinct vessels. The neural tube and the hind gut, however, usually gave a more intense response than did the surrounding tissues. In addition, the intensity of labeling of a given tissue, for example, the neural tube wall, varied somewhat with the level of the section. Whether this reflects genuine variations in the level of transcription is not known. The yolk sac was more strongly positive than on day- 10.5 p.c. sections. The labeling was present on both mesoderm and endoderm components, with the mesoderm being labeled more intensely.

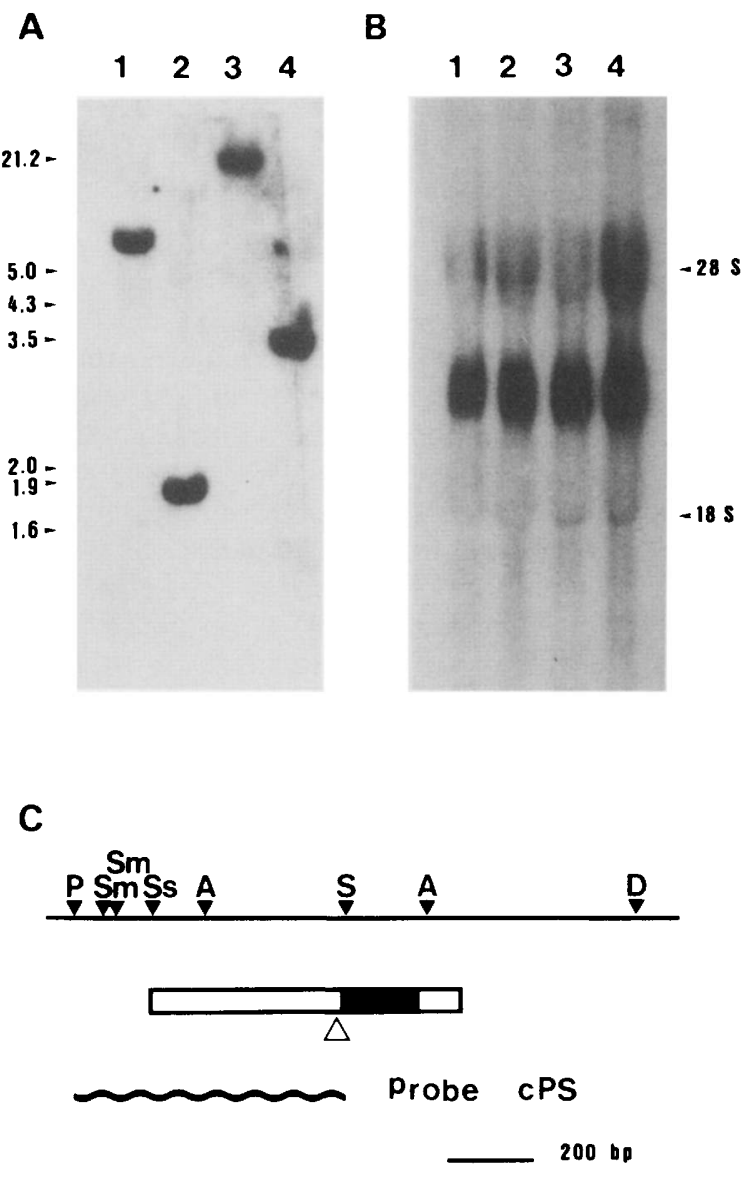

Figure 4. Genomic Southern and Northern blot analyses using the $\mathrm{cPS}$ probe under stringent hybridization conditions /see $\mathrm{Ma}$ terials and methods). (A) Southern blot of BALB/c mouse genomic DNA $(25 \mu \mathrm{g})$ restricted by HindIII, PstI, BamHI, and EcoRI (lanes 1-4). Autoradiography was done for $48 \mathrm{hr}$. Molecular weight is in kilobases. $(B)$ Northern blot of total RNA from 9.5-, 10.5-, 11.5-, and 12.5 day p.c. embryos (lanes 1-4). RNA $(40 \mu \mathrm{g})$ was loaded in each lane. Autoradiography was done for $60 \mathrm{hr}$. The mobility of rRNAs is indicated on the right. $(C) \mathrm{Re}-$ striction map of the c21 cDNA clone with its ORF. The homeo box is in black. $(\triangle)$ Position of the splicing site. The cPS probe, extending from the PstI site to the SalI site, is shown as a wavy line. (A) ApaI; (D) DraI; (P) PstI; (S) SalI; (Sm) SmaI; (Ss) SstI. 


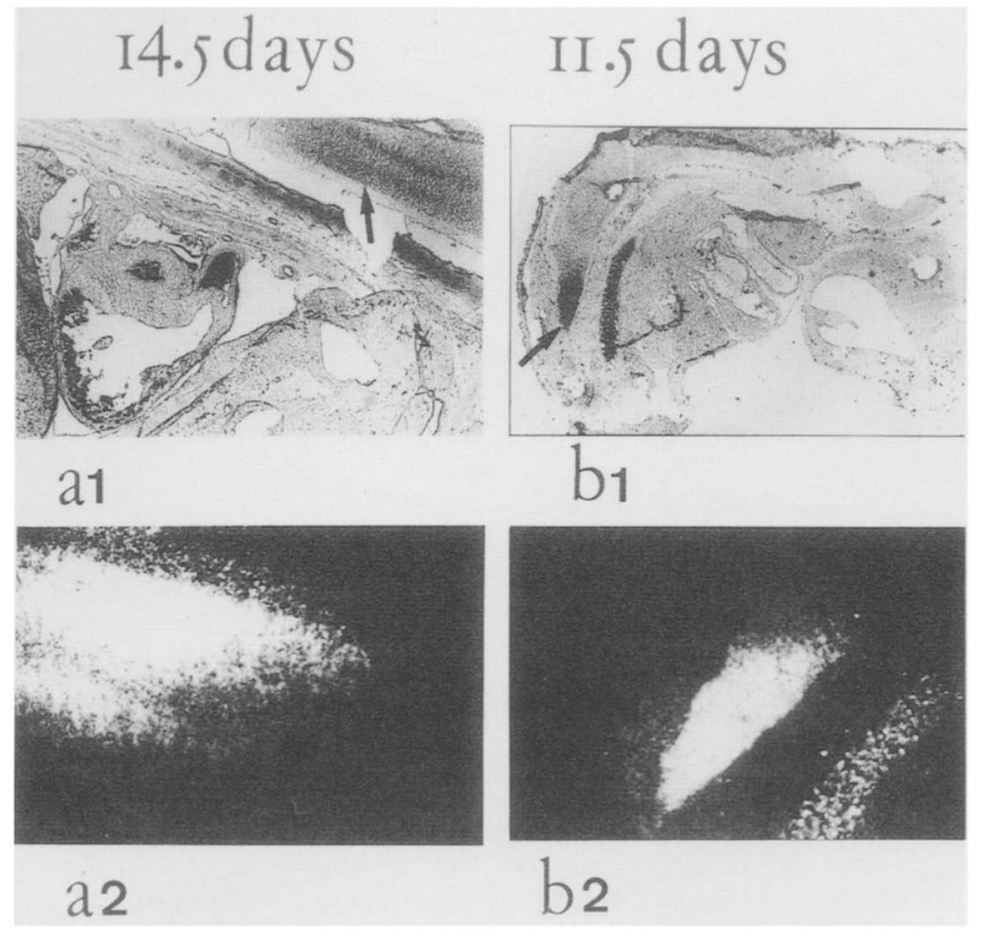

Figure 5. Localization of $H O x-3.1$ transcripts in 11.5and 14.5-day p.c. embryos. The anterior end of the embryo is on the right. $\{a 1, b 1\}$ Phase-contrast; $(a 2, b 2\}$ dark-field illumination. (a1) Parasagittal section of a 14.5-day p.c. embryo shown at the level of the heart. (b1) On this parasagittal section of a 11.5-day p.c. embryo, the neural tube, dorsal aorta, heart, and brain are shown from left to right. The arrows in $a 1$ and $b 1$ point to intensely labeled regions of the neural tube shown in $a 2$ and $b 2$, respectively. The blood cells in the dorsal aorta give an artifactual luminescence in the right part of $b 2$, which does not represent true labeling. Magnification in $a 1,340 \times ; a 2,1150 \times ; b 1$, $140 \times ; b 2,400 \times$.
Cross sections of 8.5 -day p.c. embryos yielded similar results. The signal appeared to be located in the posterior region and distributed there on all tissues, that is neural tube and hind gut as well as mesenchyme surrounding coelomic cavities, caudal veins, and aorta. However, there seemed to be less difference of labeling intensity between the various tissues (Fig. 8d2) than with 9.5-day p.c. embryonic tissues.

When sections made through a 7.5-day p.c., late primitive streak stage embryo were examined, no labeling was detectable on any embryonic or extra embryonic tissue under the conditions used (with the possible exception of the allantois, which seemed to show some labeling) (data not shown).

\section{Discussion}

The homeo gene under study here is identical to the Hox-3.1 gene described previously (Awgulewitsch et al. 1986; Breier et al. 1986), both by the nucleotide sequence of its homeo box and the restriction map of the genomic locus. We present the structure of a putative protein coded for by this gene and provide a description of Hox-3.1 transcript distribution at the time of early organogenesis.

The transcripts revealed on Northern blot or by in situ hybridization under high stringency conditions, including treatments with RNases $A+T_{1}$, should be specific for the Hox-3.1 locus. This is because the cPS probe reveals only the Hox-3.1 locus upon stringent Southern blot hybridization. However, it cannot be excluded that the mRNA species detected in 9.5- to 12.5-day p.c. embryos is heterogeneous. We are currently investigating the Hox-3.1 expression at the RNA and protein levels. In any case, the general distribution of stop codons, partic- ularly those upstream to the initiation codon, implies that the translation product described here, from the sequence of three different cDNAs, could be the main, if not the only, Hox 3.1 protein synthesized during this period of embryogenesis. This putative translation product shares extensive structural homologies, not only with other vertebrate homeo proteins but also with three truly homeotic Drosophila gene products (Antp, Ubx, $D f d)$. This suggests that these homeo proteins might be involved in molecular interactions that are more highly conserved than was thought when considering the homeo box alone.

The transcription pattern of the Hox-3.1 gene, as determined by in situ hybridization with 7.5- to 14.5-day p.c. embryos undergoes gradual modifications during the course of embryogenesis. When expression is first detected, in the 8.5-day p.c. embryo, it occurs in all tissues of the posterior region, from whichever embryonic layer they are derived. A similar pattern is still observable 1 day later, although different intensities of transcript accumulation are noticeable in different tissues, the neuroectoderm of the distal neural tube being a prominent site of Hox-3.1 expression.

Strikingly, day 10.5 p.c. of embryogenesis appears to be a transition step in Hox-3.1 transcription. The posterior transcription region becomes more weakly labeled. In contrast, an intense signal is detected in a more anterior region, at the level of the forelimb bud (i.e., at the level of somites 8-12, Hogan et al. 1986), essentially in the ventral horns of the neural tube. The dorsal region of slightly posterior somites is also strongly labeled. In the absence of any precise fate map of the mouse embryo at that stage, it cannot be determined whether cells that are positive at day 10.5 p.c. are the direct descendants of labeled 9.5-day p.c. cells. 
The pattern of transcription of Hox-3.1 detected previously in 13.5-day p.c. embryos and in newborn mice is characterized by intense expression in a highly localized area of the neural tube posterior to the third cervical vertebra (Awgulewitsch et al. 1986; Utset et al. 1987). Our results indicate that this pattern is established at

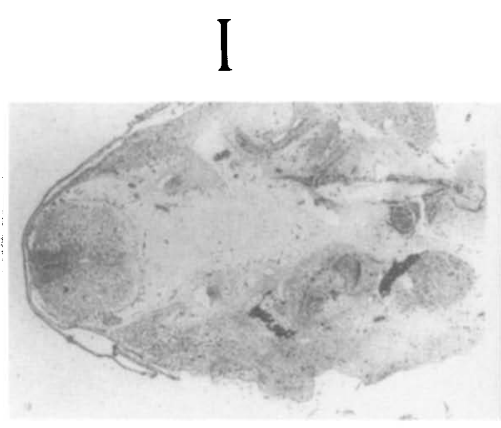

a1

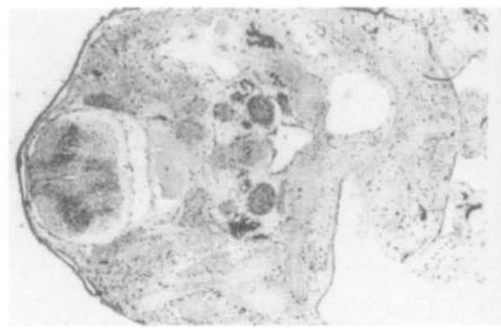

b1

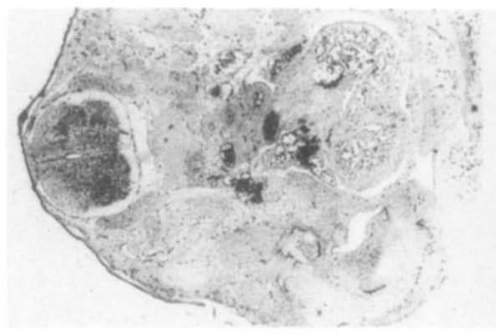

C1

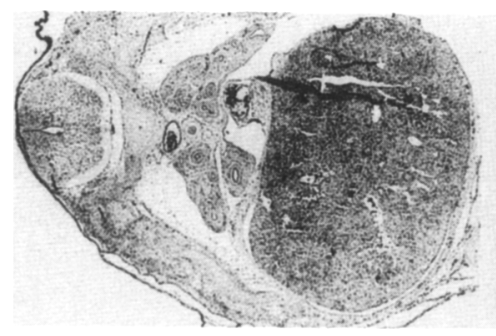

d1

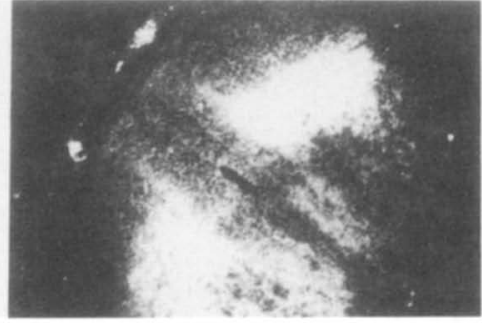

a2
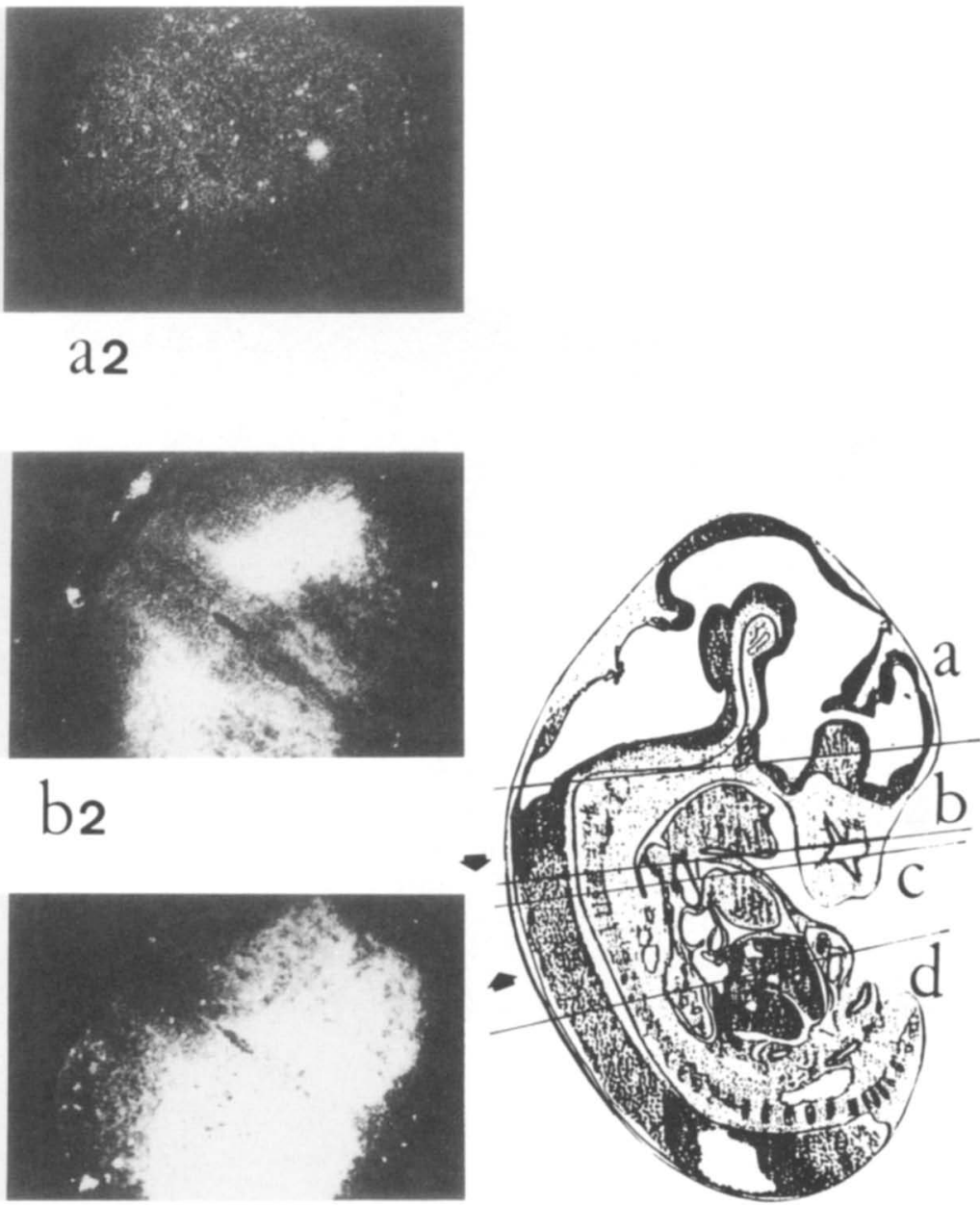

C 2

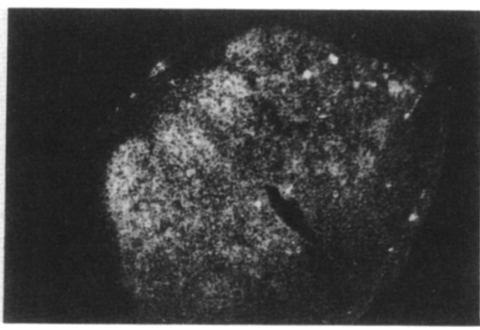

$$
\text { I 2.5 days }
$$

Figure 6. Localization of Hox-3.1 transcripts in 12.5-day p.c. embryos. (I) Transverse sections in phase-contrast illumination. The dorsal side, recognizable by the spinal cord, is on the left. Magnification, $130 \times$. (II) Dark-field illumination of the spinal cord seen in I at a higher magnification $(430 \times)$. (III) Schematized sagittal section of a 12.5-day p.c. embryo (redrawn from Rugh 1968), showing the level of sections shown in $I$ and $I I$; the two arrows bracket the region of most intense labeling in the spinal cord. (a1) Section through the spinal cord and lower head regions. (b1) Spinal cord and cervical region. (c1) Spinal cord and heart. (d1) Spinal cord, lung bud, and liver. (a2) The labeling is barely above background. $(b 2, c 2)$ Intense labeling in the mantle region of the spinal cord. (d2) Positive signal with lower intensity. 


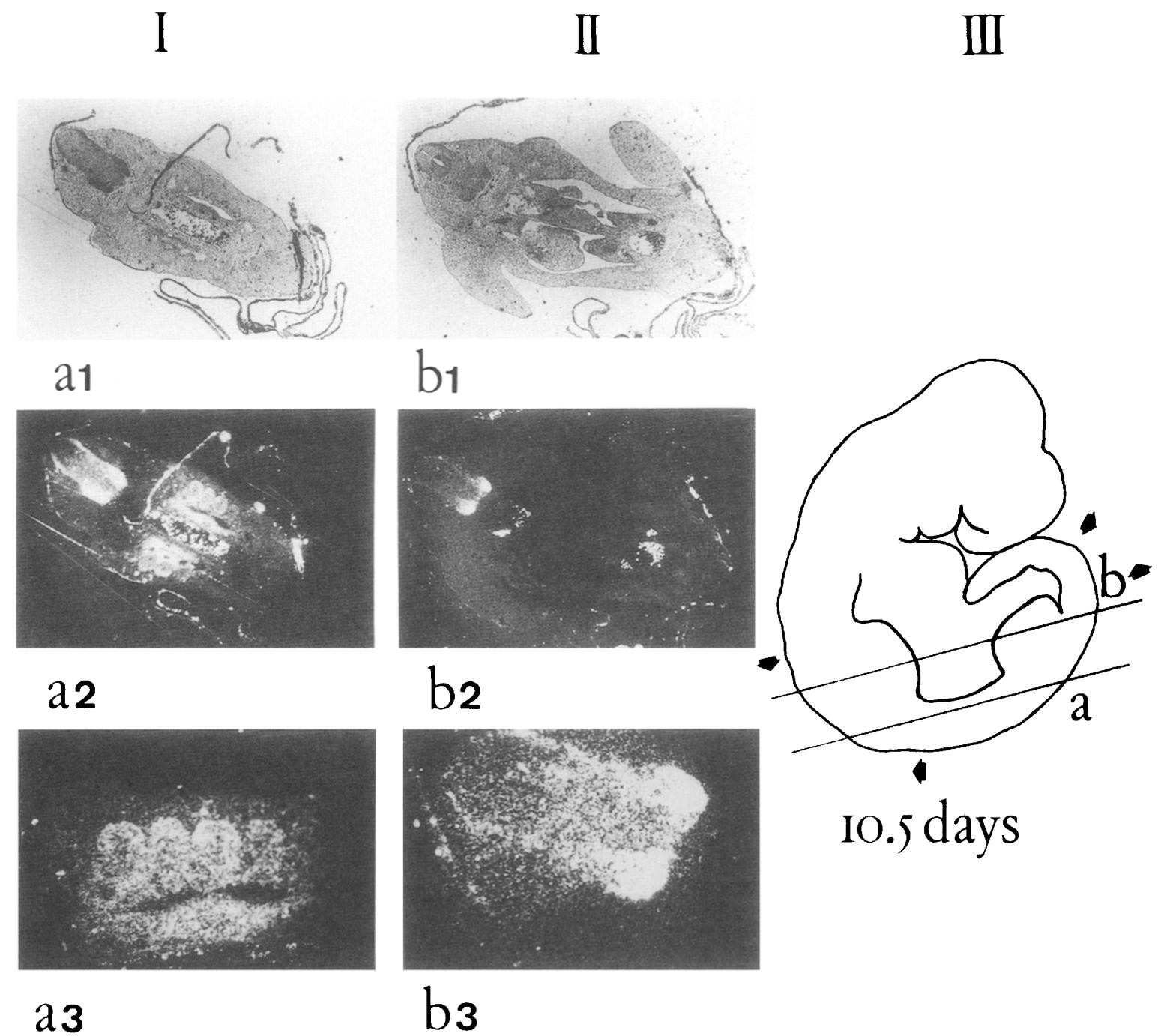

Figure 7. Localization of Hox-3.1 transcripts in 10.5-day p.c. embryo. Transverse sections shown in $I$ and $I I$ are identified as $a$ and $b$, respectively, on the diagram of an embryo in III. The anterior side is on the left. The two regions of labeling (see text) are also represented in $I I I$ by four arrows. $(a 1, b 1)$ Phase-contrast; $\{a 2, a 3, b 2, b 3)$ dark-field illumination. (a2) Labeling in the anterior part of the neural tube, especially intense on the ventral horns, and also on the somitic mesoderm shown in $a 3$ at a higher magnification. The coiled labeled ribbon in $\{a 1, a 2)$ is displaced yolk sac. (b1) A forelimb bud in the lowerleft corner and a hindlimb bud in the upper right corner. (b2) Labeling in the neural tube at the level of the forelimb bud. (b3) Anterior part of the neural tube seen in $b 2$; the signal is the most intense on the ventral horns. Note the artifactual luminescence of the dorsal aorta blood cells at the center of $a 2$ and the two sides of b2. Magnification in $a 1, a 2$ and $b 1, b 2,130 \times$; a3, b3, $450 \times$.

about day 11.5 p.c. and thus represents the outcome of a complex, gradually evolving distribution. The reorganization of the transcription pattern along the anteroposterior axis thus disclosed is accompanied by changes along the dorsoventral axis of the neural tube. Although the labeling is essentially confined to its ventral region in 10.5-day p.c. embryo, a more diffused pattern is seen on transverse sections of 12.5-day p.c. neural tube.

These results emphasize the importance of a chronological study for the understanding of homeo gene transcription patterns, as has already been pointed out by Krumlauf et al. (1987). These investigators showed that Hox-2.1 transcription occurs in tissues of different embryological lineage in the 12.5 -day p.c. mouse embryo.
In particular, a region of the neural tube posterior to the brain and mesenchymal cells around lung tubules are highly positive. It is quite conceivable that the transcription studies at earlier stages will reveal a very different pattern, as suggested by these workers.

Similarly, it will be interesting to have further information on transcript distribution of Hox-1.5, another mouse homeo gene. Gaunt et al. (1986) have shown that its expression appears to begin in different layers (ectoderm and mesoderm) of the posterior region of the embryo at a slightly earlier stage (7.5 day p.c.) than Hox-3.1. At 9.5 days p.c., expression of Hox-1.5 is essentially concentrated in a region of the neural tube posterior to the hindbrain and gradually declines toward the caudal re- 
gion. Trunk mesodermal derivatives are weakly positive at that stage. Although there is no information presently available regarding a possible evolution of this pattern, our results suggest that profound modifications could occur during this period and later.
Some features of the Hox-3.1 transcription pattern are also shared with homeo genes in other organisms. For instance, Ultrabithorax transcripts in the Drosophila embryo (Akam and Martinez-Arias 1985) are first seen in all the cells of several metameric units but later show

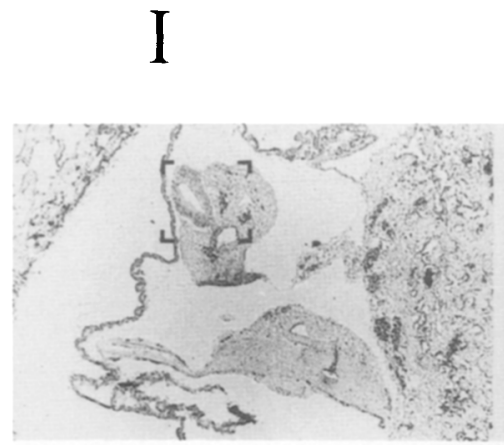

$a_{1}$

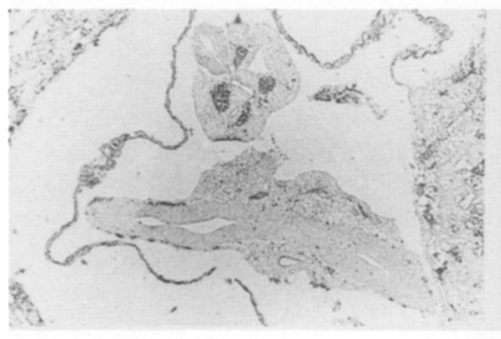

$b_{1}$

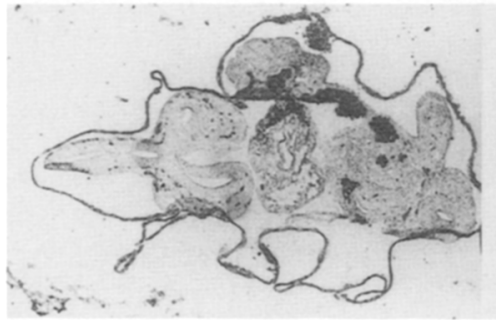

$\mathrm{C}_{1}$

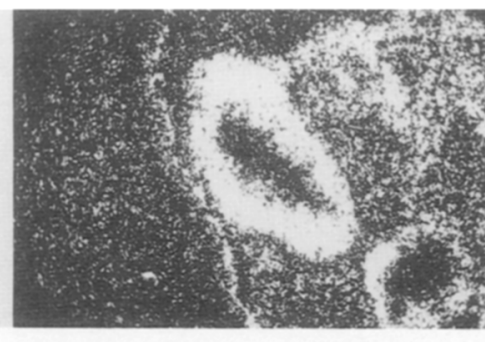

a 2

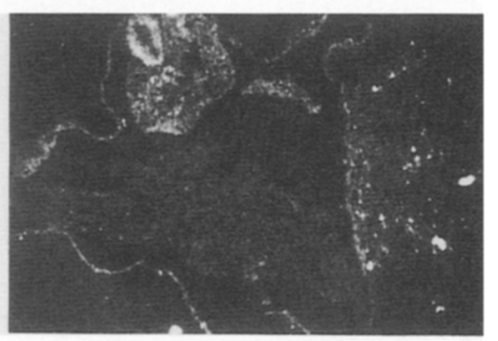

$\mathrm{b}_{2}$

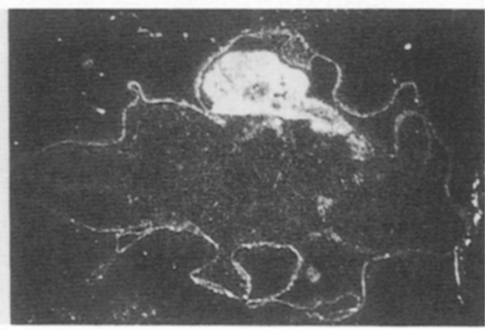

$\mathrm{C}_{2}$

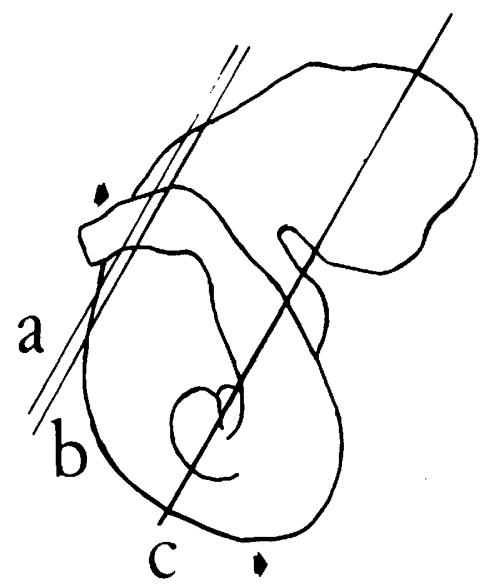

\section{5 days}

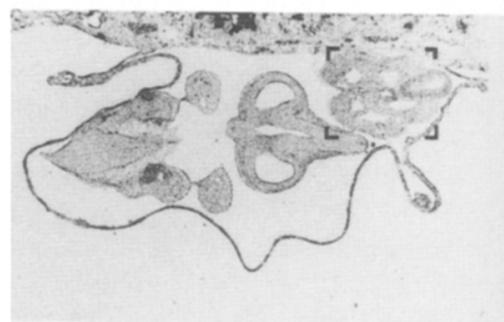

$\mathrm{d}_{1}$

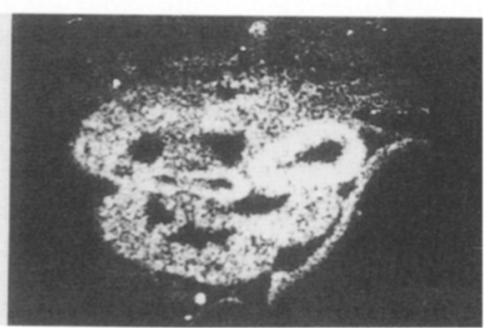

$\mathrm{d}_{2}$

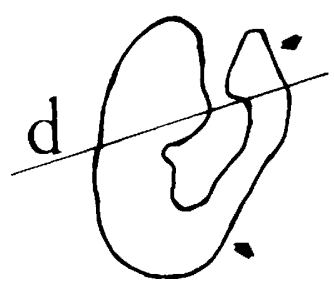

8.5 days

Figure 8. (See facing page for legend.) 
differential rates of accumulation in ectodermal and mesodermal tissues. Perhaps more relevant is the comparison with the distribution of transcripts of the Xeb 1 gene in the Xenopus embryo (Carrasco and Malacinski 1987). It is striking that there is at first a cotranscription in neurectoderm and lateral mesoderm tissues, limited to the caudal region of the neurula. Later, the labeling in the caudal neural tube decreases in the tailbud embryo and then in the swimming tadpole, whereas inversely, the Xeb 1 transcripts accumulate in the more anterior part of the neural tube, particularly in its ventral region, just posterior to the hindbrain.

The transcription pattern of the Hox-3.1 gene calls for a few preliminary remarks concerning its possible role during embryogenesis. Recent cell lineage studies in the zebra fish embryo (Kimmel and Warga 1986, 1987) have provided new information on cell determination in vertebrates. The progeny of cells marked at the blastula stage were shown to populate any germ layer, unlike those of cells marked at gastrulation, which are tissue restricted. However, the progeny of a gastrula cell can be found at any anteroposterior level of a particular germ layer. Thus, it seems that cells are determined for a layer specificity at gastrulation, but only later do they undergo regional restriction. The second of these two successive commitments might correspond to the 'nonequivalent' state postulated by Lewis and Wolpert (1976), which distinguishes cells expressing similar histotypic differentiation programs in different sections of the embryo. Little is known about cell commitment in the mouse embryo, and much of the reasoning is based on the model of the chicken (Hogan et al. 1985; Keynes and Stern 1985). In the chicken, it appears that the somitomeres of the presomitic mesoderm already carry the information required for the future somite organization, including their anteroposterior polarity (Keynes and Stern 1985). Moreover, the positional address is acquired, at the latest, at somite compaction. The first cervical somite is condensed at day 7.75 p.c., and by day 10.5 p.c., compaction of somites is completed along the whole trunk (Hogan et al. 1986, p. 17). Thus, the transcription pattern of a mouse homeo gene such as Hox-3.1, both in time and space, is compatible with its being involved in the regulation network responsible for this positioning phenomenon.

\section{Materials and methods}

Embryos

$\left.F_{1}(C 57 B L / 6) \times D B A / 2 J\right)$ females were mated with the same $F_{1}$ males and inspected daily for copulation. The day a vaginal plug was found was taken as day 0 of embryogenesis. $F_{2}$ embryos were dissected at various times of pregnancy and used for RNA extraction or cryostat sections.

\section{RNA purification}

Embryos from appropriate stages were pooled and Dounce homogenized in $5 \mathrm{M}$ guanidine monothiocyanate, $8 \% \beta$-mercaptoethanol, and $25 \mathrm{~mm}$ sodium acetate $\langle\mathrm{pH} 5.0\}$ in $7 \mathrm{ml} / \mathrm{g}$ of wet tissue (Cathala et al. 1983). RNA was selectively precipitated by $3 \mathrm{M} \mathrm{LiCl}$ and further purified by centrifugation through a cesium chloride step gradient (Maniatis et al. 1982).

\section{Construction and screening of genomic and cDNA libraries}

An SWR genomic library in $\lambda 47.1\left(9 \times 10^{5}\right.$ plaques $)$ was screened with a Drosophila Antennapedia homeo-box-containing fragment $(B a m \mathrm{HI}-\mathrm{KpnI}$ in plasmid p903G, a gift from W. Gehring). Reduced stringency hybridization was carried out at $37^{\circ} \mathrm{C}$ for $24 \mathrm{hr}$ in $43 \%$ formamide, $5 \times \mathrm{SSC}, 0.1 \%$ bovine serum albumin (BSA), $0.1 \%$ Ficoll, $0.1 \%$ polyvinylpyrolidone, $50 \mathrm{~mm}$ sodium phosphate $(\mathrm{pH} 7.0), 0.1 \%$ SDS, and $250 \mu \mathrm{g} / \mathrm{ml}$ denatured sonicated salmon sperm DNA. Subsequent washes were in $2 \times$ SSC, $0.1 \%$ SDS, twice at room temperature and twice at $50^{\circ} \mathrm{C}$ for $20 \mathrm{~min}$.

The cDNA library was constructed according to Maniatis et al. (1982). The first strand was synthesized using Moloney murine leukemia virus reverse transcriptase (GIBCO BRL), and poly(dC)-tailed using terminal deoxynucleotidyl transferase (GIBCO BRL). An oligo(dG) primer was used to synthesize the second strand using polymerase I and RNase $\mathrm{H}$. After adding EcoRI linkers, the double-stranded cDNA was inserted into $\lambda$ gt10 (Huynh et al. 1985). Screening $10^{6}$ plaques on nylon filters (Amersham) was done using a genomic fragment extending from the SalI site in the homeo box to a Sau3A site $1 \mathrm{~kb}$ downstream. Hybridization under stringent condition differed from the reduced stringency conditions (see above) in the formamide concentration $(50 \%)$, the temperature $\left(42^{\circ} \mathrm{C}\right)$, and two 30 -min washes in $0.2 \times \mathrm{SSC}, 0.1 \%$ SDS at $65^{\circ} \mathrm{C}$.

\section{DNA sequencing}

Nucleotide sequencing was performed by the dideoxynucleotide chain termination method (Sanger et al. 1977). The c21

Figure 8. Localization of Hox-3.1 transcripts at early stages of organogenesis. Transverse sections of 9.5-day p.c. $(a, b, c)$ and 8.5 -day p.c. (d) embryos. (I) Phase-contrast, (II) dark-field illumination. (III) Drawing of 9.5- and 8.5-day p.c. embryos on which are localized the levels of sections shown in $(I$ and $I I)$; the regions of labeling are enclosed by arrows. (a1) The section crosses the dorsal region almost tangentially but shows a very distal caudal region in the upper part. (a2) Enlarged view of the caudal region framed in $a 1$; the labeling is most intense in the neural tube and hind gut but is also present on surrounding mesoderm tissues and the yolk sac. (b1) Section longitudinal to the dorsal region and transversal to the caudal region (in the upper part). (b2) No labeling in the dorsal region, including the neural tube; the tissue distribution of labeling in the caudal region is the same as in $a 2$; bright spots on the right are due to blood cells in the placenta. (c1) The section crosses, from left to right, brain, heart, and trunk with the neural tube and a forelimb bud and, in the upper part, a caudal region. (c2) Labeling only in the caudal region, in all tissues, and on the surrounding yolk sac. (d1) From left to right, an anterior region, with the neural tube, pharyngeal cavity, and brain and, in the upper right part, a distal caudal region. (d2) Enlarged view of the caudal region framed in $d 1$, showing the neural tube on the right; labeling on the yolk sac and on all tissues of the caudal region. Magnification in $a 1, b 1, b 2, d 1,200 \times ; a 2,700 \times ; c 1, c 2,170 \times ; d 2,450 \times$. 
clone was inserted into Bluescript plasmid (Stratagene cloning system) and deleted by the exonuclease III-mung bean nuclease method. Subclones of c21, c1, and c26 cDNAs and specific genomic regions were obtained in the M13 phage or Bluescript and sequenced.

\section{Blot hybridization}

DNAs from $B A L B / c$ and SWR were prepared by classical methods (Maniatis et al. 1982) and, after restriction and electrophoresis, transferred to nylon membranes (Amersham). RNAs were electrophoresed in denaturing formaldehyde gels (Maniatis et al. 1982) and transferred to NEN GeneScreen Plus membranes. The PstI-SalI cDNA fragment was labeled to a specific activity of $1.5 \times 10^{9} \mathrm{cpm} / \mu \mathrm{g}$ using the multiprime labeling system (Amersham). Blots were hybridized with the denatured DNA probe at $42^{\circ} \mathrm{C}$, for $17 \mathrm{hr}$, with $2 \times 10^{6} \mathrm{cpm} / \mathrm{ml}$ in $20 \mathrm{ml}$ of $1 \mathrm{M} \mathrm{NaCl}, 1 \%$ SDS, $50 \%$ formamide, and $10 \%$ dextran sulfate and washed twice at $65^{\circ} \mathrm{C}$ for $30 \mathrm{~min}$ in $200 \mathrm{ml}$ of $2 \times$ SSC, $1 \%$ SDS.

Synthesis of sense and antisense RNA probes from $\mathrm{T} 7$ and $\mathrm{T} 3$ RNA polymerase promoters in the Bluescript vector were performed according to Melton et al. (1984), using [ $\alpha^{-32}$ P]UTP (800 $\mathrm{Ci} / \mathrm{mmole}$, Amersham) and RNA polymerases from Pharmacia (T7) and GIBCO BRL (T3). Blots were hybridized with singlestranded RNA probes at $55^{\circ} \mathrm{C}$ for $24 \mathrm{hr}$ in $50 \%$ formamide, 0.3 $\mathrm{M} \mathrm{NaCl}, 20 \mathrm{~mm}$ sodium phosphate $(\mathrm{pH} 6.8\}, 1 \%$ SDS, $100 \mu \mathrm{g} / \mathrm{ml}$ denatured salmon sperm DNA, and $300 \mu \mathrm{g} / \mathrm{ml}$ baker's yeast RNA, washed twice at $65^{\circ} \mathrm{C}$ for $30 \mathrm{~min}$ in $2 \times \mathrm{SSC}, 1 \%$ SDS, treated at $37^{\circ} \mathrm{C}$ for $30 \mathrm{~min}$ with RNases A $(40 \mu \mathrm{g} / \mathrm{ml})$ and $T_{1}(2$ $\mu \mathrm{g} / \mathrm{ml}$, rinsed in $2 \times \mathrm{SSC}$, and further washed twice for $30 \mathrm{~min}$ at $65^{\circ} \mathrm{C}$ in $0.2 \times \mathrm{SSC}, 0.1 \% \mathrm{SDS}$. Alternative washes after RNases treatments were at $55^{\circ} \mathrm{C}$ in hybridization buffer minus dextran sulfate for $24 \mathrm{hr}$.

\section{In situ hybridization analysis}

Cryostat sections were obtained from embryos fixed with $4 \%$ paraformaldehyde and processed as described (Brûlet et al. 1985). The sense and antisense cPS probes were synthesized using T3 and T7 RNA polymerases (see above) to a specific activity of about $1.5 \times 10^{9} \mathrm{cpm} / \mu \mathrm{g}$ with $\left.{ }^{35} \mathrm{~S}\right] \mathrm{UTP} \alpha \mathrm{S}(\beta 1000 \mathrm{Ci}$ / mmole, Amersham). The sizes of the probes were monitored on $6 \%$ acrylamide sequencing gels. Sections were hybridized (Hogan et al. 1986) for $24 \mathrm{hr}$ at $55^{\circ} \mathrm{C}$ with $2 \times 10^{6} \mathrm{cpm}$ in $20 \mu \mathrm{l}$ of a mixture containing $50 \%$ formamide, $10 \%$ dextran sulfate, $0.3 \mathrm{M} \mathrm{NaCl}, 10 \mathrm{~mm}$ Tris $-\mathrm{HCl}, 10 \mathrm{~mm}$ sodium phosphate $(\mathrm{pH}$ 6.8), $5 \mathrm{~mm}$ EDTA, $0.02 \%$ Ficoll $400,0.02 \%$ polyvinylpyrolidone, $0.02 \% \mathrm{BSA}$, and $20 \mathrm{~mm}$ dithiothreital (DTT). Sections were washed for $1 \mathrm{hr}$ at $55^{\circ} \mathrm{C}$ in the hybridization buffer, $30 \mathrm{~min}$ at $37^{\circ} \mathrm{C}$ in $2 \times \mathrm{SSC}$, treated with $40 \mu \mathrm{g} / \mathrm{ml} \mathrm{RNase} \mathrm{A} \mathrm{and} 2 \mu \mathrm{g} / \mathrm{ml}$ RNase $\mathrm{T}_{1}, 30 \mathrm{~min}$ at $37^{\circ} \mathrm{C}$ in $2 \times \mathrm{SSC}$, rinsed in $2 \times \mathrm{SSC}$, and further washed for $24 \mathrm{hr}$ at $55^{\circ} \mathrm{C}$ in hybridization buffer minus dextran sulfate. Autoradiographies were for $2-3$ weeks. Phasecontrast and dark-field photographs were obtained with an Olympus IMT2 microscope with $4.0 \times$ and $10.0 \times$ objectives and a Zeiss Axiophot with a $2.5 \times$ objective.

\section{Acknowledgments}

We would like to thank Pr. F. Jacob for his constant support, L. Parada for his advice in the Northern experiments and for reading the manuscript, $C$. Henderson and M. Yaniv for critically reading the manuscript, and Mrs. D. Boullier and Mrs. M. Maury for their excellent technical assistance. This work was supported by grants from the Centre National de la Recherche
Scientifique (UA 1148), INSERM (CR 851004), the Fondation pour la Recherche Medicale, and the ARC (CR 6609).

\section{Note added in proof}

These sequence data have been submitted to the EMBL/GenBank Data Libraries under the accession number Y00215.

\section{References}

Akam, M.E. and A. Martinez-Arias. 1985. The distribution of Ultrabithorax transcripts in Drosophila embryos. EMBO $\%$. 4: $1689-1700$.

Awgulewitsch, A., M.F. Utset, C.P. Hart, W. McGinnis, and F.H. Ruddle. 1986. Spatial restriction in expression of a mouse homoeo box locus within the central nervous system. Nature 320: 328-335.

Birnstiel, M.L., M. Busslinger, and K. Strub. 1985. Transcription termination and $3^{\prime}$ processing: The end is in site! Cell 41: 349-359.

Brier, G., M. Bucan, U. Francke, A.M. Colberg-Poley, and P. Gruss. 1986. Sequential expression of murine homeo box gene during F9 EC cell differentiation. EMBO I. 5: 22092215.

Brûlet, P., H. Condamine, and F. Jacob. 1985. Spatial distribution of transcripts of the long repeated ETn sequence during early mouse embryogenesis. Proc. Natl. Acad. Sci. 82: 2054-2058.

Carrasco, A.E. and G.M. Malacinski. 1987. Localization of Xenopus homeo-box gene transcripts during embryogenesis and in the adult nervous system. Dev. Biol. 121: 69-81.

Cathala, G., J.-F. Savouret, B. Mendez, B.L. West, M. Karin, J.A. Martial, and J.D. Baxter. 1983. A method for isolation of intact, translationally active ribonucleic acid. DNA 2: 329335.

Cavener, D.R. 1987. Comparison of the consensus sequence flanking translational start sites in Drosophila and vertebrates. Nucleic Acids Res. 15: 1353-1361.

Cech, T.R. 1983. RNA splicing: Three themes with variations. Cell 34: 713-716.

Colberg-Poley, A.M., S.D. Voss, K. Chowdhury, and P. Gruss. 1985a. Structural analysis of murine genes containing homoeo box sequences and their expression in embryonal carcinoma cells. Nature 314: 713-718.

Colberg-Poley, A.M., S.D. Voss, K. Chowdhry, C.L. Stewart, E.F. Wagner, and P. Gruss. 1985b. Clustered homeo boxes are differentially expressed during murine development. Cell 43: 39-45.

Duboule, D., A. Baron, P. Mähl, and B. Galliot. 1986. A new homeo-box is present in overlapping cosmid clones which define the mouse HOX-1 locus. EMBO I. 5: 1973-1980.

Fainsod, A., L.D. Bogarad, T. Ruusala, M. Lubin, D.M. Crothers, and F.H. Ruddle. 1986. The homeo domain of a murine protein binds $5^{\prime}$ to its own homeo box. Proc. Natl. Acad. Sci. 83: $9532-9536$.

Gaunt, S.J., J.R. Miller, D.J. Powell, and D. Duboule. 1986. Homeobox gene expression in mouse embryos varies with position by the primitive streak stage. Nature 324: 662-664.

Gehring, W.J. 1987. Homeotic genes, the homeobox, and the spatial organization of the embryo. Harvey Lect. 81: 153172.

Gergen, J.P. 1987. Drosophila segmentation genes and blastoderm cell identities. BioEssays 6: 61-66.

Hart, C.P., A. Awgulewitsch, A. Fainsod, W. McGinnis, and F.H. Ruddle. 1985. Homeo box gene complex on mouse chromosome 11: Molecular cloning, expression in embryo- 
genesis, and homology to a human homeo box locus. Cell 43: $9-18$.

Harvey, R.P., C.J. Tabin, and D.A. Melton. 1986. Embryonic expression and nuclear localization of Xenopus homeobox (Xhox) gene product. EMBO J. 5: 1237-1244.

Hauser, C.A., A.L. Joyner, R.D. Klein, T.K. Learned, G.R. Martin, and R. Tjian. 1985. Expression of homologous homeo-box-containing genes in differentiated human teratocarcinoma cells and mouse embryos. Cell 43: 19-28.

Hogan, B., P. Holland, and P. Schofield. 1985. How is the mouse segmented? Trends Genet. 1: 67-74.

Hogan, B., F. Costantini, and E. Lacy. 1986. Manipulating the mouse embryo: A laboratory manual. Cold Spring Harbor Laboratory, Cold Spring Harbor, New York.

Holland, P.W.H. and B.L.M. Hogan. 1986. Phylogenetic distribution of Antennapedia-like homeo boxes. Nature 321: 251-253.

Huynh, T.V., R.A. Young, and R.W. Davis. 1985. Constructing and screening cDNA libraries in $\lambda$ gt10 and $\lambda$ gt 11 . In DNA cloning: A practical approach (ed. D.M. Glover), vol 1, pp. 49-78. IRL Press, Oxford.

Joyner, A.L. and G.R. Martin. 1987. En-1 and En-2, two mouse genes with sequence homology to the Drosophila engrailed gene: Expression during embryogenesis. Genes Dev. 1: $29-38$.

Keynes, R.J. and C.D. Stern. 1985. Segmentation and neural development in vertebrates. Trends Neurosci. 8: 220-223.

Kimmel, C.B. and R.M. Warga. 1986. Tissue-specific cell lineages originate in the gastrula of the Zebrafish. Science 231: $365-368$.

Kimmel, C.B. and R.M. Warga. 1987. Cell lineages generating axial muscle in the Zebrafish embryo. Nature 327: 234237.

Krumlauf, R., P.W.H. Holland, J.H. McVey, and B.L.M. Hogan. 1987. Developmental and spatial patterns of expression of the mouse homeobox gene, Hox 2.1. Development 99: 603617.

Laughon, A. and M.P. Scott. 1984. Sequence of a Drosophila segmentation gene: Protein structure homology with DNAbinding protein. Nature 310: 25-30.

Lewis, J.H. and L. Wolpert. 1976. The principle of non-equivalence in development. I. Theor. Biol. 62: 479-490.

MacDonald, P.M. and G. Struhl. 1986. A molecular gradient in early Drosophila embryos and its role in specifying the body pattern. Nature 324: 537-545.

Maniatis, T., E.F. Fritsch, and J. Sambrook. 1982. Molecular cloning: A laboratory manual. Cold Spring Harbor Laboratory, Cold Spring Harbor, New York.

Martinez-Arias, A. and P. Ingham. 1986. Form and diffusion. Nature 324: 510-511.

Mavilio, F., A. Simeone, A. Giampaolo, A. Faiella, V. Zappavigna, D. Acampora, G. Poiana, G. Russo, C. Peschle, and E. Boncinelli. 1986. Differential and stage-related expression in embryonic tissues of a new human homeobox gene. Nature 324: 664-667.

McGinnis, W., R.L. Garber, J. Wirz, A. Kuroiwa, and W.J. Gehring. 1984. A homologous protein-coding sequence in Drosophila homeotic genes and its conservation in other metazoans. Cell 37: 403-408.

Melton, D.A., P.A. Krieg, M.R. Rebagliati, T. Maniatis, K. Zinn, and M.R. Green. 1984. Efficient in vitro synthesis of biologically active RNA and RNA hybridization probes from plasmids containing a bacteriophage SP6 promoter. Nucleic Acids Res. 12: 7035-7056.

Mlodzik, M., A. Fjose, and W.J. Gehring. 1985. Isolation of caudal, a Drosophila homeo box-containing gene with ma- ternal expression, whose transcripts form a concentration gradient at the pre-blastoderm stage. EMBO /. 4:29612969.

Regulski, M., N. McGinnis, R. Chadwick, and W. McGinnis. 1987. Developmental and molecular analysis of Deformed; a homeotic gene controlling Drosophila head development. $E M B O$ I. 6: 767-777.

Rugh, R. 1968. The mouse: Its reproduction and development. Burgess Publishing Company, Minneapolis.

Sanger, F., S. Nicklen, and A.R. Coulson. 1977. DNA sequencing with chain-terminating inhibitors. Proc. Natl. Acad. Sci. 74: 5463-5467.

Schneuwly, S., A. Kuroiwa, P. Baumgartner, and W.J. Gehring. 1986. Structural organization of the homeotic gene Antennapedia of Drosophila melanogaster. EMBO I. 5: 733-739.

Schofield, P.N. 1987. Patterns, puzzles and paradigms: The riddle of the homeobox. Trends Neurosci. 10: 3-6.

Shepherd, J.C.W., W. McGinnis, A.E. Carrasco, E.M. De Robertis, and W.J. Gehring. 1984. Fly and frog homeo domains show homologies with yeast mating type regulatory proteins. Nature 310: 70-71.

Snow, M.H.L. 1986. New data from mammalian homeoboxcontaining genes. Nature 324: 618-619.

Utset, M.F., A. Awgulewitsch, F.H. Ruddle, and W. McGinnis. 1987. Region-specific expression of two mouse homeo box genes. Science 235: 1379-1382.

Wilde, C.D. and M. Akam. 1987. Conserved sequence elements in the $5^{\prime}$ region of the Ultrabithorax transcription unit. $E M B O$ I. 6: $1393-1401$. 


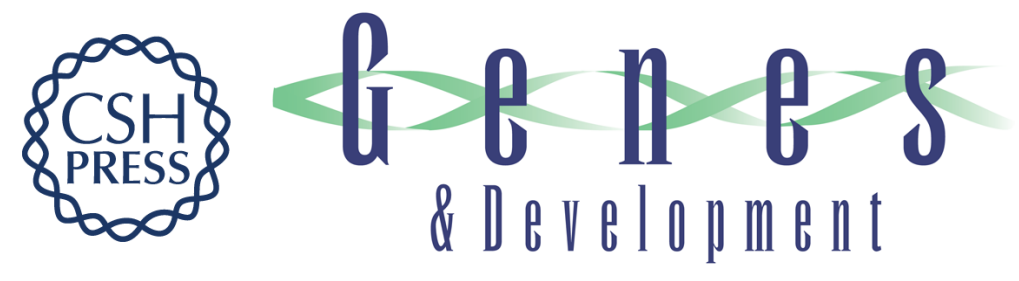

\section{Pattern of transcription of the homeo gene Hox-3.1 in the mouse embryo.}

H Le Mouellic, H Condamine and P Brûlet

Genes Dev. 1988, 2:

Access the most recent version at doi:10.1101/gad.2.1.125

References This article cites 42 articles, 6 of which can be accessed free at: http://genesdev.cshlp.org/content/2/1/125.full.html\#ref-list-1

\section{License}

Email Alerting

Receive free email alerts when new articles cite this article - sign up in the box at the top Service right corner of the article or click here.

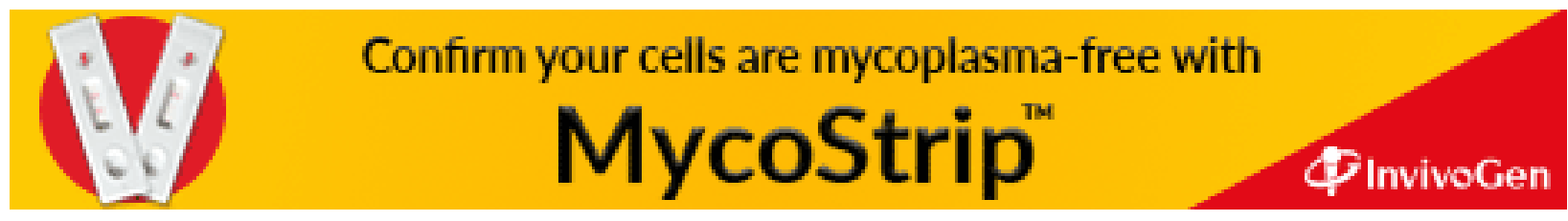

